\author{
Michą Flieger, Ryszard Kamińs KI
}

\title{
Corporate Consistency and the Regulations of the Corporate Governance System
}

\section{Introduction}

In contemporary organizations the management process is constantly changing. This is due to the fact that new trends are continuously emerging and they have a significant influence on corporate practice. The trends concern the external surroundings in which companies operate, as well as their internal environment. The main external changes are connected with economic and geopolitical conditions, but also with a new model of the consumer based on postmodernist theory, called 'the postmodern consumer.'The internal changes are connected mainly with a new era of workers and with a turn to nonmaterial values in management, but also with the necessity of applying the latest technology.

Management system transformation is a process, which means that it is taking place all the time and, moreover, on each level of management in an organization. As it concerns all the levels, there is a problem of overall planning and coordination, especially from the perspective of the board. ${ }^{1}$ The problem starts when we try to analyze and construct consistency within an organization, because no operational models are available. At this point specific questions arise, and answers are required since they are crucial not only for an in-depth understanding of the problem but also for practical application. This is one of the most important issues for researchers of management theory nowadays, because business and public managers require support with regard to consistency within organizations, which may be the key to building a competitive advantage in a modern way.

Trying to respond to the challenges mentioned above, we decided to provide a holistic picture of modern corporate governance from two perspectives. The first considers the internal role of the board as the main body responsible for the efficiency and effectiveness of operations. The second analyzes the relationship between companies and their

1 A. Dignam, M. Galanis, The Globalization of Corporate Governance, Burlington 2009. 
environment. Both pictures create a synergy effect and provide a general view of modern corporate governance practices and problems.

To accomplish this aim, the author of the first part of the paper tries to operationalize the process of corporate consistency by establishing the concept of corporate consistency. The concept consists of certain consistency platforms which are described in detail below. This is the first time that this concept has been introduced in an international publication. There are also auxiliary aims, such as: to introduce a corporate consistency model, to describe consistency platforms, and to point out the main problems in implementing the consistency process. To make the topic more understandable the author attempts to exemplify the corporate consistency building process by referring to companies with mature process structures. Process structures are introduced more and more often in modern organizations, so connecting consistency with process structures seems to be very important from both a theoretical and practical point of view. At the end of the first part of the paper, the author suggests the directions in which further studies of the topic should be taken.

The second part focuses on corporate governance regulations as an element of a broadly understood system of company management, including the management of a company's relationship with entities from their business environment. This section aims to present and evaluate the corporate governance system, focusing in particular on the EU and Polish regulations introduced following changes to conditions. The main thesis of this part of the article is the assumption that general trends in the development of corporate governance regulations outlined by international organizations, including EU directives and Polish regulations, show the right direction and should be given credit. Drafts of new regulations and recently adopted ones take into account the current trends in the development of enterprises and markets. However, further successful development of the corporate governance system requires the cooperation of many actors involved in the creation of this system. This means that the development of EU and Polish rules concerning the corporate governance system should be based on the cooperation of all the stakeholders involved in the formation of this system. The provisions quoted in the paper were enforced on 31 December 2015.

\section{Corporate consistency in management theory}

The topic of management consistency rarely appears in management theory, and when it does it is not analyzed in depth. Moreover, no operational studies have been carried out and no models have been constructed so far. However, some authors deal with the issue and a short overview will be presented below.

R. Coolidge approaches the consistency problem by pointing out that consistency is practicing what you preach, which means that actions should be consistent with 
words. ${ }^{2}$ This way the author focuses our attention on creating an appropriate corporate culture which is flexible enough to adapt to different periods in a company's life cycle.

Coolidge helps companies evaluate if they are consistent by listing some characteristics of consistent companies. They are:

- low employee turnover, high motivation and morale,

- high customer satisfaction, loyal customers,

- customers can accurately describe your company's culture, and embrace it,

- rapid growth after a period of slow growth or decline,

- growth after a period of decline exceeds previous successes, indicating the incorporation of learning and consistency

According to E. Brackett, consistency relates to a company's brand and to be consistent means deciding on specific visual elements, such as a name, logo, logotype, color and design system to be used throughout the company ${ }^{3}$. This approach, although important, only refers to a narrow meaning of consistency, focusing on brand creation. A similar approach is represented by S. Robshow-Bryan, who stresses the need for brand consistency, ${ }^{4}$ and A. Lynch, who gives examples of good (consistent) and bad brands. ${ }^{5}$

A. Pulido, D. Stone and J. Strevel analyze corporate consistency from the customer's point of view. ${ }^{6}$ They insist that to increase customer satisfaction, sales rate and revenues, companies should be consistent with regard to: having clear policies, rules, and supporting mechanisms to ensure consistency during each interaction; positive customer emotional experience - reflected in a feeling of trust; ensuring customers recognize the delivery of promises, which requires proactively shaping communications and key messages that consistently highlight delivery as well as themes. In this approach, consistency also relates to a given part of companies' activities regarded as general clues as to what companies should remember about.

A different view on consistency is represented by H. Cronqvist, A. Makhija and S. Yonker, who associate consistency with human resource management and employment policy. ${ }^{7}$ They point out that each CEO should be individually matched to the

2 R. Coolidge, Corporate Consistency, Executive Blueprint, http://www.executiveblueprints.com/ tips/080503_corporateconsistency.htm [access: 6.10.2016].

3 E. Brackett, Why Consistency is important?, Visible Logic, http://www.visiblelogic.com/ blog/2009/04/why-consistency-is-so-important-to-branding/ [access: 6.10.2016].

4 S. Robshow-Bryan, The importance of brand consistency, Surfire 2013.

5 A. Lynch, A difference between a good brand and a great brand. Consistency, Nortbstar Marketing, http://www.northstarmarketing.com/2015/05/07/the-difference-between-a-good-brand-anda-great-brand-consistency [access: 8.10.2016].

6 A. Pulido, D. Stone, J. Strevel, The three Cs of customer satisfaction: Consistency, consistency, consistency, March 2014.

7 H. Cronqvist, A. Makhija, S. Yonker, Behavioral consistency in corporate finance: CEO personal and corporate leverage, "Journal of Financial Economics" 2012, vol.103, no. 1, pp. 20-40. 
position in the company according to the exact position description and requirements. Only such detailed requirements make it possible to decide if a candidate is right for the position or not. Importantly, the authors advise using the behavioral consistency theory to match people to their functions.

As we can see, consistency is presented in management theory in a very specific way - there are some attempts to analyze consistency in certain areas of business operations. The most popular area is connected with marketing and the company-customer relationship. However, there has been no attempt to analyze consistency from a general perspective, where the board should plan and implement consistent actions.

\section{The foundation of the consistency concept - general systems theory}

Consistency theory is based on Ludwig von Bertallanfy's general systems theory. One of the most important assumptions of this theory is that changes influence not only other elements of the system, but also the effectiveness of the whole system. According to general systems theory, a change in one element of the system influences the other elements and hence the functioning of the whole system changes. Thus, optimization of one element of the system (suboptimization) may have three effects on the whole system: it may improve its effectiveness, deteriorate its effectiveness or have no results at all.

When we look at an organization as a system, the conclusions drawn from general systems theory have a key meaning for organizational harmonization and optimization. When we optimize an organization by implementing constant changes we need to see it and analyze it as one system, and we need to look in different directions, which means searching for possible effects of changes in various areas of the functioning of the organization. Possible effects may also appear in areas located far away from each other.

The assumptions of general systems theory are characterized by a high level of abstraction. The problem becomes apparent when we try to put these assumptions into practice. To do so, we need to identify the main areas where changes are needed and show the interaction between them. Only then will we be able to identify how possible changes in one area influence other areas. This way, the process of harmonization, adjusting and consistency building among different organizational areas will be identified, which will allow us to implement changes. This will lead to an increase in organizational effectiveness. For this reason the author of the first part of this paper introduces platforms for the creation of consistency.

Another important conclusion resulting from general systems theory is an opportunity to see an organization from the perspective of systems, subsystems and suprasystems. It is known that systems consist of subsystems, but at the same time systems are 
the elements of suprasystems. Subsystems may join to create systems and systems join to create suprasystems. This mechanism was used by the author to construct the concept of consistency presented below.

\section{Corporate consistency platforms}

Before consistency platforms are introduced, a crucial remark needs to be made - although the platforms are universal for any organization, their internal construction must be adjusted to the strategic level of every organization: to its mission, vision, strategy and strategic goals. Since each organization has a different strategic level construction, the internal shape of the consistency platforms in each case will be different, and will need to be adjusted appropriately. Such an approach is necessary and has one big advantage, namely the need to think over strategic issues first, before further decisions on consistency are made. In many organizations the strategic level is neglected or even abandoned ${ }^{8}$.

The consistency concept proposed in this part of the paper consists of three consistency platforms. Each of them should create a consistent system and when this condition is met all the elements of each platform are harmonized and consistent. The platforms are presented in Table 1.

Table 1. The platforms of organizational consistency

\begin{tabular}{|c|c|c|c|}
\hline Platform Number & First element & Second element & $\begin{array}{c}\text { Effect of } \\
\text { harmonization }\end{array}$ \\
\hline Platform 1 & Management concepts & Management methods & Consistent system \\
\hline Platform 2 & $\begin{array}{c}\text { Organizational } \\
\text { structure }\end{array}$ & $\begin{array}{c}\text { Management style } \\
\text { and mechanisms }\end{array}$ & Consistent system \\
\hline Platform 3 & Platforms 1+2 & $\begin{array}{c}\text { Human resource (pro- } \\
\text { file, practices) }\end{array}$ & Consistent system \\
\hline
\end{tabular}

Source: own study.

As we can see from the table above, harmonization takes place on three platforms of consistency. Each platform consists of two elements which should constitute a consistent system.

The first platform refers to two elements which in the theory and practice of management logically complement each other - the concepts and methods of management. Introducing a chosen concept triggers the need to introduce other concepts, so that the first one is supported by complementary concepts. Thus, even in the area of concepts

8 K. Obłój, Strategia organizacji, Warszawa 1999, p. 74. 
there are some consistent subsystems. Furthermore, introducing certain management concepts triggers the need to implement the specific management methods which result from the choice of those concepts. When we think about methods it is not only important to implement them, but also to adjust and accommodate them according to the concepts and all the methods implemented. So, again here we end up with a consistent subsystem, but this time in the area of methods, which is adjusted to the concepts. As we can see, the proposed consistency platforms allows the harmonization of some subsystems which are internally consistent to be sought, and in moving up to the system level they join a consistent system. This approach is presented in Figure 1.

\begin{tabular}{|c|c|c|c|c|}
\hline $\begin{array}{l}\text { Consistent subsystem of } \\
\text { management concepts }\end{array}$ & + & $\begin{array}{l}\text { Consistent subsystem of } \\
\text { management concepts }\end{array}$ & $=$ & Consistent system \\
\hline
\end{tabular}

Figure 1. Consistency system in organizational harmonization exemplified by platform 1

Source: own study.

Using the terminology of general systems theory it may be said that if the concepts and methods of management constitute a consistent system, then their internal minisystems constitute consistent subsystems of the whole system. It also refers to other platforms which may be perceived as consistent subsystems of the whole consistent system. Here we move on different levels of a system analysis.

Platform two, as we can see in Table 1, consists of two key elements. The first one is an organizational structure and the other the appropriate style and mechanisms of management in the organization. In each organization there is an organizational structure that requires a specific management style which managers prefer, as well as mechanisms they use so that the two elements are appropriately adjusted. Generally speaking, organizational structures may be functional structures, process structures (and process-like structures, e.g. virtual), and also hybrid structures are a combination of functional and process structures. Each of the structures mentioned differs with regard to its functioning and requires adjusting the management style and recognizing the mechanisms which are natural for the structure. When the mechanisms are recognized and understood in the organization, they must be used actively by managers on all company levels.

The third platform in Table 1 is the platform which integrates the previously analyzed platforms with human resource management in the organization. This platform shows that the human resources of the company must be adjusted to the consistent systems of the concepts and methods of management, and to the organizational structure and style and the mechanisms of management. The human capital of the organization must have some characteristics which are matched to the requirements resulting from the previous platforms. 
Thus, platform three consists of a consistent subsystem made up of two subsubsystems (Platforms 1 and 2) and a subsystem of human resource. The last one requires special adjustment inside human resource management in the organization. These adjustments may be in the area of human resource practices and other activities resulting from the determined human resource profile. Platform 3 also underlines the key role and intersystem character of human resources in the organization, which are the basis of the efficient and effective functioning of all the other systems mentioned on Platform 1 and 2.

\section{Organizational consistency model}

According to the analysis presented above, it is possible to construct an organizational consistency model on the strategic level of corporate management. The model summarizes the analysis made on the specific consistency platforms. It is presented in Figure 2.

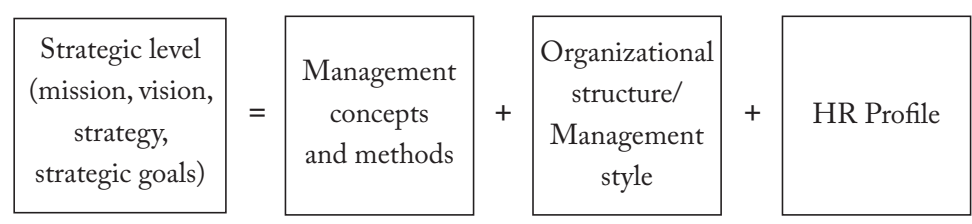

Figure 2. Organizational consistency model

Source: own study.

As we can see in Figure 2, the foundation of organizational consistency and the harmonization of organizational assumptions and activities is always built on the strategic level of an organization, which is its mission, vision, strategy and strategic goals. The strategic level influences the harmonization of all the other subsystems that we can see in the model. Thus, the model shows platforms where necessary analyses resulting from a consistent system have to be carried out. When such a system is achieved, the effectiveness and efficiency of the organization is optimized.

What needs to be underlined is the fact that the subsystems presented above in the model (consistency platforms) are open, which means that analysis platforms may be added to the model if necessary. The platforms presented in the model in Figure 2 are obligatory for the analysis in the company, but there is a possibility to add new analysis subsystems. This way a consistency model may inspire managers, which is a very important value of the model. The inspiring character of the model is presented in Figure 3.

As we can see from the above, the consistency model has an open nature. Importantly, the model is also flexible, which means its subsystems can be reconfigured accordingly to fit to the changes in the internal and external environment of an organization (internal reconfiguration of subsystems). The internal reconfiguration may be temporary or 
permanent. Temporary reconfiguration means modifications in the subsystems when compared to the configuration made before. This kind of situation may arise when, for example, in times of crisis in an organization the democratic management style is replaced by an autocratic one, in order to solve problems quickly. Then the workers only follow orders. When the situation of the company improves and the problems are solved then there is a return to the previous model.

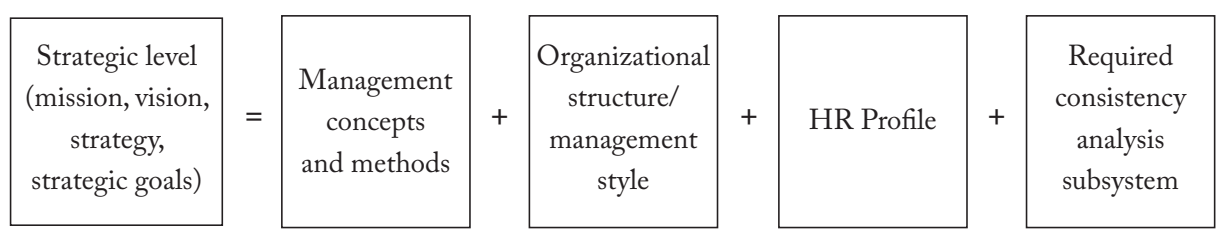

Figure 3. Consistency platforms configuration - open model type

Source: own study.

Permanent reconfiguration means changing the subsystems and their regulations according to permanent environment changes or new experiences gained ${ }^{9}$. What is important here is feedback regarding the effectiveness of the regulations which are part of the subsystems. Such a communication system allows for organizational learning and changing subsystems accordingly.

Temporary and permanent reconfiguration of the model subsystems means that, due to the consistency concept introduced by the author, it is natural that reconfiguration of the subsystems is optimized all the time and changes are introduced when they are required. Consequently, managers must be involved in consistency management almost on a daily basis.

When permanent and profound changes of the regulation model within an organization take place, then the strategic level of the company changes (the mission, vision, strategy, strategic goals), and so does the functioning of the model. Then often a new subsystems configuration is necessary. For example, such a situation may arise when an organization changes its structure from functional to process-oriented, and when process management is introduced. The changes are complex and actually model subsystems are formed from the very beginning. What is important is that the change does not have to concern the elements proposed in the model in Figure 3, but only the regulations inside the consistency subsystems.

9 M.M. Blair, Reforming Corporate Governance: What History Can Teach US, Berkeley 2004, pp. 39-40. 


\section{Corporate governance - an external approach}

Corporate governance can be defined as a system of rules, practices and processes by which a company is directed and controlled. Corporate governance essentially involves balancing the interests of many stakeholders in a company, namely its shareholders, management, customers, suppliers, financiers, government and the community. Since corporate governance also provides a framework for attaining a company's objectives, it encompasses practically every sphere of management, from action plans and internal controls to performance measurement and corporate disclosure. ${ }^{10}$

The main issues regulated by the principles of corporate governance include:

- relationships with shareholders, contractors and employees,

- the disclosure of conflicts of interest,

- the establishment of objectives and identification of factors and mechanisms to monitor the achievement of these objectives,

- the shaping of the organisational structure, segregation of roles and duties,

- the information and communication system,

- risk management,

- the system of internal control,

- external and internal audit.

The notion of corporate governance was first formulated by the Organization for Economic Cooperation and Development in its Principles of Corporate Governance ${ }^{11}$. It was meant to serve as a helping tool in the assessment and improvement of the legal framework, relevant institutions and binding regulations existing in the countries where a system of exercising influence on shareholders' supervision is in place. According to the OECD, corporate governance is a system through which economic organizations are managed and supervised. It is expected that good corporate governance will motivate the management to focus on meeting the company's objectives and use the company's resources efficiently. It should also facilitate successful monitoring of the company's business, thus counteracting improper or overtly fraudulent accounting practices and financial fraud.

In the preamble, of the OECD Principles of Corporate Governance we can read that:

Corporate governance involves a set of relationships between a company's management, its board, its shareholders and other stakeholders. Corporate governance also

10 Corporate Governance, Investopedia, http://www.investopedia.com/terms/c/corporategovernance.asp [access: 23.09.2013].

11 OECD Principles of Corporate Governance, OECD, 6 October 1999, http://www.oecd-ilibrary. org/governance/oecd-principles-of-corporate-governance_9789264173705-en [access:23.09. 2013]. 
provides the structure through which the objectives of the company are set, and the means of attaining those objectives [...] are determined. Good corporate governance should provide proper incentives for the board and management to pursue objectives that are in the interests of the company and its shareholders and should facilitate effective monitoring. The presence of an effective corporate governance system, within an individual company and across an economy as a whole, helps to provide a degree of confidence that is necessary for the proper functioning of a market economy. As a result, the cost of capital is lower and firms are encouraged to use resources more efficiently, thereby underpinning growth. ${ }^{12}$

The five basic areas covered by the OECD Principles of Corporate Governance are:

1. Protection of the rights of shareholders,

2. Equitable treatment of all shareholders, comprising full disclosure of material information as well as the prohibition of abusive self-dealing and insider trading,

3. Equitable treatment of all stakeholders as established by law, and encouragement of cooperation between the company and its stakeholders,

4. Timely and accurate disclosure and transparency with respect to the matters pertinent to company performance, ownership and governance,

5. Strategic guidance of the company and effective monitoring of its management by the board of directors, as well as the board's accountability to the company and its shareholders ensured by the corporate governance framework.

The Principles are non-binding and do not aim at detailed prescriptions for national legislation. They seek to identify objectives and suggest various means for achieving them. Their purpose is to serve as a reference point. According to the intention of the OECD:

They can be used by policy makers as they examine and develop the legal and regulatory frameworks for corporate governance that reflect their own economic, social, legal and cultural circumstances, and by market participants as they develop their own practices. The Principles are evolutionary in nature and should be reviewed in light of significant changes in circumstances. To remain competitive in a changing world, corporations must innovate and adapt their corporate governance practices so that they can meet new demands and grasp new opportunities. ${ }^{13}$

The OECD Principles are referenced by countries developing their local codes or guidelines. In 2002, on the basis of a consultative process and ISAR's deliberations and 
building on the Principles of the OECD, the Intergovernmental Working Group of Experts on International Standards of Accounting and Reporting (ISAR) at UNCTAD prepared a report entitled Transparency and disclosure requirements for corporate governance. ${ }^{14}$ An updated version entitled Guidance on Good Practices in Corporate Governance Disclosure was published in $2006 .{ }^{15}$ These guidelines consist of more than fifty distinct disclosure items across five broad categories:

- auditing,

- the board and management structure and process,

- corporate responsibility and compliance in the organisation,

- financial transparency and information disclosure,

- the ownership structure and exercise of control rights.

\section{EU regulations}

The EU Member States and the European Union have made a significant contribution to the development of corporate governance standards. The OECD principles of corporate governance have been developed on the basis of the principles of good practice in the $\mathrm{UK}^{16}$. In the European Union a range of different corporate governance codes has been developed at the national and international level. The structure of these codes is very similar, but the solutions are not always the same. Corporate governance systems reflect the history, culture, economic development, social values and legal system of each country. All the codes, however, attempt to create some patterns of behaviour that can achieve a real (not just a formal) alignment of the rights and the position occupied by various corporate actors (shareholders, managers, creditors, etc.).

The European Union has achieved a great deal in terms of enhancing corporate governance in the EU. The background to the debate in the European Union on corporate governance began with the report of the High Level Group of Company Law Experts in 2002. This report, entitled "A Modern Regulatory Framework for Company Law in Europe" 17 focused on corporate governance and the modernisation of company law. This report concluded that the EU should not attempt to develop a pan-European code,

14 Transparency and Disclosure Requirements for Corporate Governance: Report by the Ad Hoc Consultative Group of Experts on Corporate Governance Disclosures, United Nations Conference on Trade and Development, TD/B/COM.2/ISAR/15 26 July 2002 (1.10.2013).

15 Guidance on Good Practices in Corporate Governance Disclosure, United Nations Conference on Trade and Development, New York - Geneva 2006.

16 The principles of good practice are included in the Cadbury's report, Greenbury's and Hampel's reports and Turnbull's report.

17 A Modern Regulatory Framework for Company Law in Europe, The High Level Group of Company Law Experts, Brussels, 4 November 2002, http://ec.europa.eu/internal_market/company/ docs/ modern/report_en.pdf [access: 14.02.2017]. 
but rather consider "a certain coordination" of corporate governance codes to encourage further convergence. This convergence should focus on both, reducing barriers to crossborder voting by shareholders, as well as to the information that affects shareholders' ability to evaluate the governance of companies.

In 2007, the Commission published two other reports reviewing Member States' implementation of Member States of the Commission Recommendations on independent directors and directors' remuneration. ${ }^{18}$ The findings of the reports show that all Member States have issued corporate governance codes and most codes are applied on a complyor-explain basis. However, the reports identify certain areas where the recommended principles have not been adequately followed. ${ }^{19}$

In 2014, the European Commission announced a new proposal to improve corporate governance within the European Union - Commission Recommendation of 9 April 2014 on the quality of corporate governance reporting ('comply or explain'). ${ }^{20}$ The proposal aims to improve corporate governance reported by the listed companies. The purpose of this Recommendation is to provide guidance to the bodies of Members States responsible for national corporate governance codes, companies and other parties concerned. The guidance aims to improve the overall quality of corporate governance statements published by companies in accordance with Article 20 of Directive 2013/34/EU²1 and, specifically, the quality of explanations provided by companies in the case of ignoring the recommendations of the relevant corporate governance code.

The European Commission commented that there were "shortcomings in the way the 'comply or explain' principle is applied" by European listed companies. This refers to the situation when "companies often do not provide appropriate explanations when they depart from corporate governance codes". The Recommendation mainly aims to "provide guidance on how listed companies should explain their departures from the recommendations of the relevant corporate governance codes." It will not be legally binding but it is nevertheless intended to "improve the overall quality of corporate governance statements published by companies." According to the decision of the European Com-

18 Report on the application by Member States of the EU of the Commission Recommendation on directors' remuneration, Brussels, 13.07.2007, SEC (2007) 1022.

19 A Guide to Corporate Governance Practices in the European Union, International Finance Corporation, World Bank Group, 2015, http://www.ifc.org/wps/wcm/connect/c44d6d00 47b7597bb7d9f7299ede9589/CG_Practices_in_EU_Guide.pdf?MOD=AJPERES [access: 22.09.2016], pp. 5-8.

20 Commission Recommendation of 9 April 2014 on the quality of corporate governance reporting ('comply or explain') (2014/208/EU), Official Journal of the European Union L 109/43.

21 Directive 2013/34/EU of The European Parliament and of The Council of 26 June 2013 on the annual financial statements, consolidated financial statements and related reports of certain types of undertakings, amending Directive 2006/43/EC of the European Parliament and of the Council and repealing Council Directives 78/660/EEC and 83/349/EEC, Official Journal of the European Union L 182/19 2013. 
mission, the EU Member States should draw this Recommendation to the attention of the bodies responsible for national corporate governance codes, listed companies and other parties concerned.

The unique important step in the subject of corporate governance was the adoption in 2014 of Directive 2014/95/EU, ${ }^{22}$ which requires the disclosure of non-financial and diverse information by certain large businesses. In particular, large public interest entities with more than 500 employees will be required to disclose certain nonfinancial information in their management reports. This includes listed companies as well as some unlisted companies, such as banks, insurance companies, and others that are so designated by Member States because of their activities, size, or the number of employees. The scope includes approximately 6,000 large companies and groups across the EU.

According to this Directive, a non-financial report should contain information relating to, as a minimum:

- a brief description of the company's business model,

- a description of the policies pursued by the company in relation to those matters, including due diligence processes implemented,

- the outcome of those policies,

- the principal risks related to those matters linked to the company's operations including, where relevant and proportionate, its business relationships, products or services which are likely to cause adverse impacts in those areas, and how the company manages those risks,

- non-financial key performance indicators relevant to the particular business.

According to the preamble to Directive 2014/95UE the report should disclose:

- environmental matters (e.g. health and safety, use of renewable and/or nonrenewable energy, greenhouse gas emissions, water use and air pollution),

- social and employee-related matters (e.g. gender equality, implementation of the fundamental conventions of the International Labour Organization, working conditions, social dialogue, respect for the right of workers to be informed and consulted, respect for trade union rights, health and safety at work and the dialogue with local communities, and/or the actions taken to ensure the protection and the development of those communities),

- human rights matters (e.g. information on the prevention of human rights abuses), anti-corruption and bribery matters (e.g. information on instruments in place to fight corruption and bribery).

22 Directive 2014/95/EU of The European Parliament and of the Council of 22 October 2014 amending Directive 2013/34/EU as regards disclosure of non-financial and diversity information by certain large undertakings and groups, Official Journal of the European Union, L 330/1 2014. 
Thus, non-financial reports contain a lot of information in the area of corporate governance. The directive leaves significant flexibility for companies to disclose relevant information in the way they consider most useful, or in a separate report. Companies may use the international, European, or national guidelines that they consider appropriate (for example, the UN Global Compact, ISO 26000, or the German Sustainability Code).

The main problem for the European Commission has been to design a single system in the context of widely differing legal traditions and ownership structures. Undoubtedly the European Union has come some way toward convergence because of the wide acceptance of the 'comply or explain' principle, but it can be argued that there is little agreement in many of the detailed corporate governance practices and norms, and in particular the gulf remains wide between markets with dispersed ownership and those with controlling shareholders. ${ }^{23}$ Many corporate governance commentators believe that the EU corporate governance initiatives have succeeded in bringing about substantial convergence, harmonization, and unification in corporate governance regimes among its Member States. ${ }^{24}$

There is general agreement that EU directives have created a solid framework for improving corporate governance in its Member States and have triggered many corporate governance improvements. European Commission Directive 2006/46/EC required all listed companies to produce a corporate governance statement in their annual report to shareholders for the first time. This and other EU corporate governance reforms have succeeded in bringing about substantial convergence in corporate governance regimes among the Member States. Some European countries and some international bodies very strongly support corporate governance in diverse ways. They assume that developing corporate governance practices is conducive to increasing competitiveness and sustainable development among European companies. ${ }^{25}$

\section{Polish regulations}

Good corporate governance practices are known in Poland under the name of 'good practices. ${ }^{26}$ They combine the generally accepted principles of good governance with the norms that govern a company's investor relations with the environment. Their main

23 A Guide to Corporate Governance..., op. cit., pp. 5-8.

24 I. Ivaschenko, P. Brooks, Corporate governance reforms in the EU: Do they matter and how?, IMF Working Paper WP/08/91, Washington DC 2008, cit. after: A Guide to Corporate Governance..., op. cit.

25 A Guide to Corporate Governance..., op. cit., pp. 5-8.

261 January 2016 a modified set of corporate governance rules came into force, namely Best Practices of WSE Listed Companies 2016. 
objective is to strengthen the transparency of listed companies, improve the quality of their communication with the investor community, as well as to provide better protection of shareholders' rights.

Good governance principles specify the proceedings at annual general meetings, the running of management meetings, and the relations of the above bodies with external people and institutions, including the manner of selecting the auditor and publishing company information. What is noteworthy is that the principles of good governance require companies to publish a confirming statement in their annual reports if these principles have been adopted and implemented. If a company derogates from acting in accordance with corporate governance, that fact must be disclosed to the public and the reasons for such derogation must be stated.

An important step in the development of good governance practices in Poland was the drafting of the Good Governance Code, which was done by the Polish Forum of Corporate Governance ${ }^{27}$ (Forum - Corporate Governance, 2005). The recommendations of the Code address the problems that often arise when one dominant shareholder effectively takes control of a company. Another issue regulated by the code is the proper audit mechanisms in situations involving a substantial dispersion of shareholders. The fundamental principle adopted in the Code is that a company must operate in a manner that fosters the common interest of each and every shareholder, regardless of the number of shares held.

The good practices of WSE Listed Companies combine the generally accepted principles of corporate governance standards concerning the relations between listed companies and their business environment. Their aim is to strengthen the transparency of listed companies, improve the quality of their communication with investors, and to strengthen the protection of shareholder rights. Good Practices focus on the areas where their use can have a positive impact on the market valuation of companies, thus reducing the cost of capital. The rules formulated by the Best Practices Committee determine desirable practices concerning the general meeting, the management boards of companies, and the relationship of these bodies with external persons and institutions, including the principle for the selection of an auditor and the ways to share information about companies. It should be emphasized that these policies have been imposed on the company as a commitment to public disclosure in the annual report on corporate governance. In the case of deviations from these, the company should disclose this and provide reasons.

In order to facilitate the implementation of good governance practices by Polish companies, the Stock Exchange at www.corp-gov.gpw.pl has designed a page to provide all

27 Dobre praktyki w spótkach publicznych 2005, Komitet Dobrych Praktyk, Forum - Corporate Governance, Warszawa 2005, http://www.corp-gov.gpw.p1/assets/library/polish/dp2005.pdf [access: 5.05.2011]. 
the necessary information and material that companies may use to adopt and follow the practices, including updated or current information on recent developments in this field. The website aims to promote good governance and create a discussion forum for the exchange of opinions between the Stock Exchange and interested parties, listed companies and others. There are links to documents promoting good governance or facilitating its implementation, other relevant publications, as well as references or links to the websites of institutions engaged in promoting good governance in companies.

The obligation to report on corporate governance for listed companies stems from the provisions of Directive 2013/34/EU (Article 20) and the Accounting Act ${ }^{28}$ (Article 49 $\S 2$ ), which states that this should be done in the annual report. The scope of information on this issue is defined in the Ordinance of the Minister of Finance of 19 February 2009 on current and periodic information disclosed by issuers of securities and the conditions of recognising this information as equivalent to the information required by the laws of non-EU Member States. ${ }^{29}$ According to $§ 91$ paragraph 5 point 4 of the Ordinance statement, corporate governance should include a description of the internal control, risk management and financial reporting process.

The question of information on corporate governance is also the subject of the National Accounting Standard No. 9 Report on the activities. In this standard, it is assumed that this information should include a description of the internal control and risk management, the process for the preparation of financial statements, together with an evaluation.

\section{Conclusions}

In the contemporary highly competitive and demanding business environment it is necessary for companies to search for new, innovative ways to be effective and efficient. The consistency concept proposed in the first part of the paper presents an internal viewpoint in corporate governance and creates new possibilities in this area. The possibilities concern an ongoing search for consistency by harmonizing various organization management areas which create subsystems for analysis. This permanent consistency search is based on system theory and results from the strategic level of the company. ${ }^{30}$ Consistent thinking is one of the main tasks of contemporary managers at all organizational levels:

28 Accounting Act of 29 September 1994 (Dz.U. no. 121 item 591).

29 Ordinance of the Minister of Finance dated 19 February 2009 on current and periodic information disclosed by issuers of securities and the conditions of recognising this information as equivalent to the information required by the laws of non-EU Member States, (Dz.U. no. 3 item 259).

30 C.M. Daily, D. R. Dalton, A.A. Cannella, Corporate Governance: Decades of Dialogue and Data, "Academy of Management Review" 2003, vol. 28, no. 3, pp. 375-376. 
strategic, tactical and operational. It should be of course initiated and monitored by the board..$^{31}$

The scope of the consistency analysis in the organization is determined by the management level. Here, the zooming process appears. For example, in a process organization the operational level and the consistency analysis may concern only one process, whereas in a functional organization it my concern just one function (e.g. sales, finance). However, zooming must be a part of the consistency concept in each organization. The consistency concept is the basis for the zooming process - the concept is operationalized at lower management levels.

To achieve organizational consistency there must be a sequence of activities within the company. First, the theoretical assumptions of the consistent system are formulated, and then the series of projects which implement the theoretical concept are introduced. When the projects are finished we may say that the organization has achieved maturity in its consistency. This means that it may be possible to construct an organizational consistency maturity model as the steps toward consistency are made. Once the consistency maturity has been achieved there is ongoing consistency management, because the search for consistency never ends - the changing environment makes it one of the basic everyday managerial tasks. In this way consistency is similar to the process management and process maturity of an organization. This analogy should inspire further analysis of how the consistency concept is applied in practice. ${ }^{32}$

When there is no consistency awareness in an organization and the consistency concept is not present, many problems may result from this state of affairs. Then the effectiveness and efficiency of an organization decreases and the value added for the client is lower than it could be. All this makes the competitive position of the organization worse. The main reasons why the consistency concept is neglected are lack of consistency awareness and knowledge on how to build consistency in theory, and then how to operationalize it. There are no alternatives to the consistency model presented in this paper. There are also no experiences which may be used by organizations in a consistency search. Moreover, to become consistent it is necessary to make an organizational effort, which may be discouraging.

These problems create challenges for researchers. Firstly, it is necessary to make the necessary efforts to widen the awareness and knowledge concerning the consistency concept among managers. Secondly it is necessary to search for operational solutions regarding consistency implementation in organizations.

31 European Corporate Governance. Cleaning the Augean Tables. Corporate Governance in Continental Europe is Improving Rapidly, "The Economist” June 2011.

32 M. Flieger, Zarzadzanie procesowe w urzędach gmin. Model adaptacji kryteriów dojrzatości procesowej, Poznań 2012, p. 120. 
The consistency concept and the consistency model proposed in this paper may be a starting point for operational solutions, such as developing: diagnosis questionnaires, consistency maturity models (both descriptive and prescriptive), consistency model modifications, and other solutions that make consistency more understandable and easier to implement. One of the biggest problems nowadays is how to measure the level of consistency within an organization. No complex questionnaires and measures are available, and designing them poses challenges to management theory nowadays. As we can see, there is a lack of knowledge and the tools which can be found in the literature may be used in consistency search only to a limited extent, because they were designed for other purposes. A good example is a diagnostic questionnaire for learning organizations. ${ }^{33}$

Summing up, the consistency concept and the consistency model proposed by the authors suits the most modern trends in management connected with search for effectiveness, efficiency and competitive advantage. Moreover, it fills a knowledge gap existing in the literature and brings new possibilities for managers in organizations. This concept has an implementation value, which makes it attractive for practitioners. It is also universal so it may be used in any kind of an organization. Moreover, the proposed concept may inspire other management specialists and scientists to fill a knowledge gap in the organizational consistency area.

On the other hand, from an external point of view, corporate governance is affected by the relationships among participants in the governance system. Controlling stakeholders can significantly influence corporate behaviour. Institutional investors are increasingly demanding a voice in corporate governance. Individual shareholders usually do not seek to exercise governance rights, but may be very concerned about obtaining fair treatment from controlling shareholders and management. Creditors play an important role in a number of governance systems and can serve as external monitors over the corporate performance. Employees and other stakeholders play an important role in contributing to the long-term success and performance of the corporation, while governments establish the overall institutional and legal framework for corporate governance. The role of each of these participants and their interactions varies widely in different countries, including the EU Member States. These relationships are subject, in part, to law and regulation and, in part, to a voluntary adaptation and, most importantly, to market forces. The degree to which corporations adhere to the basic principles of good corporate governance is an increasingly important factor for investment decisions. Following good corporate governance practices can help to improve the confidence of investors, reduce the cost of capital and thus enhance the functioning of markets, and ultimately induce more stable economic development.

33 M. Czerska, R. Rutka, Metody diagnozowania przedsiębiorstwa, Katowice 1998, p. 69. 
As has been described, in Polish regulations concerning the application of the principles of corporate governance, emphasis is placed on the control system of accounting and corporate financial reporting. It was assumed that this is a prerequisite for improving the quality of financial reporting, as well as reducing the possibility of actions that cause damage to the company and its stakeholders, including the falsification of accounting and other crimes. As a result, the application of the principles of corporate governance and publishing information about the area increases companies' credibility. With the introduction of a code of good practice, the Polish capital market has become more transparent, and thus more competitive for European partners. For many companies, the application of the principles of corporate governance is followed by an increase in their share prices on the stock exchange.

\section{Literature}

A Guide to Corporate Governance Practices in the European Union, International Finance Corporation, World Bank Group, 2015, http://www.ifc.org/wps/wcm/ connect/c44d6d0047b7597bb7d9f7299ede9589/CG_Practices_in_EU_Guide. pdf?MOD=AJPERES [access: 22.09.2016].

A Modern Regulatory Framework for Company Law in Europe, The High Level Group of Company Law Experts, Brussels, 4 November 2002, http://ec.europa.eu/internal_market/company/docs/ modern/report_en.pdf [access: 14.02.2017].

Blair M.M., Reforming Corporate Governance: What History Can Teach Us, Berkeley 2004. Brackett E., Why Consistency is important?, Visible Logic, http://www.visiblelogic.com/ blog/2009/04/why-consistency-is-so-important-to-branding/ [access: 6.10.2016].

Commission Recommendation of 9 April 2014 on the quality of corporate governance reporting ('comply or explain') (2014/208/EU), Official Journal of the European Union L 109/43.

Coolidge R., Corporate Consistency, Executive Blueprint, http://www.executiveblueprints.com/tips/080503_corporateconsistency.htm [access: 6.10.2016].

Corporate Governance, Investopedia, http://www.investopedia.com/terms/c/corporategovernance.asp [access: 23.09.2013].

Cronqvist H., Makhija A., Yonker S., Behavioral consistency in corporate finance: CEO personal and corporate leverage, "Journal of Financial Economics" 2012, vol. 103, no. 1.

Czerska M., Rutka R., Metody diagnozowania przedsiębiorstwa, Katowice 1998.

Daily C.M., Dalton D.R., Cannella A.A., Corporate Governance: Decades of Dialogue and Data, "Academy of Management Review" 2003, vol. 28, no. 3.

Dignam A., Galanis M., The Globalization of Corporate Governance, Burlington 2009.

Dobre praktyki spótek notowanych na GPW, Appendix to Resolution no. 19/1307/2012 of Council Board of 21 November 2012. 
European Corporate Governance. Cleaning the Augean Tables. Corporate Governance in Continental Europe is Improving Rapidly, “The Economist” June 2011.

Flieger M., Zarzadzanie procesowe w urzędach gmin. Model adaptacji kryteriów dojrzatości procesowej, Poznań 2012.

Guidance on Good Practices in Corporate Governance Disclosure, United Nations Conference on Trade and Development, New York - Geneva 2006.

Ivaschenko I., Brooks P., Corporate governance reforms in the EU: Do they matter and how? IMF Working Paper WP/08/91, International Monetary Fund, Washington DC 2008, cit. after: A Guide to Corporate Governance Practices in the European Union, International Finance Corporation, World Bank Group, 2015.

Komitet Dobrych Praktyk, Forum - Corporate Governance, (2005), Dobre praktyki w spótkach publicznych 2005, Warszawa. Retrieved May 5, 2011 from http://www.corp-gov.gpw. $\mathrm{pl} /$ assets/library/polish/dp2005.pdf.

Lynch A., A difference between a good brand and a great brand. Consistency, Northstar Marketing, http://www.northstarmarketing.com/2015/05/07/the-difference-between-agood-brand-and-a-great-brand-consistency [access: 8.10.2016].

Obłój K., Strategia organizacji, Warszawa 1999.

OECD Principles of Corporate Governance, OECD, 6 October 1999, http://www.oecdilibrary.org/governance/oecd-principles-of-corporate-governance_9789264173705-en [access: 23.09.2013].

OECD Principles of Corporate Governance, OECD, 29 April 2004.

Pulido A., Stone D., Strevel J., The three Cs of customer satisfaction: Consistency, consistency, consistency, March 2014.

Report on the application by Member States of the EU of the Commission Recommendation on directors' remuneration, Brussels, 13.07.2007, SEC (2007) 1022.

Robshow-Bryan S., The importance of brand consistency, Surfire 2013.

The EU Approach to Corporate Governance, Essentials and Recent Developments, International Finance Corporation, World Bank Group, Washington DC 2008, http://www. ifc.org/wps/wcm/connect/f515ff804af4fc7da869b9b94e6f4d75/IFC_EUApproach_ Final.pdf?MOD=AJPERES [access: 14.02.2017].

Transparency and Disclosure Requirements for Corporate Governance: Report by the Ad Hoc Consultative Group of Experts on Corporate Governance Disclosures, United Nations Conference on Trade and Development, TD/B/COM.2/ISAR/15 26 July 2002 (1.10.2013).

Accounting Act of 29 September 1994 (Dz.U. no. 121 item 591).

Directive 2013/34/EU of The European Parliament and of The Council of 26 June 2013 on the annual financial statements, consolidated financial statements and related reports of certain types of undertakings, amending Directive 2006/43/EC of the Euro- 
pean Parliament and of the Council and repealing Council Directives 78/660/EEC and 83/349/EEC, Official Journal of the European Union L 182/19 2013.

Directive 2014/95/EU of The European Parliament and of the Council of 22 October 2014 amending Directive 2013/34/EU as regards disclosure of non-financial and diversity information by certain large undertakings and groups, Official Journal of the European Union, L 330/1 2014.

Ordinance of the Minister of Finance dated 19 February 2009 on current and periodic information disclosed by issuers of securities and the conditions of recognising this information as equivalent to the information required by the laws of non-EU Member States (Dz.U. no. 3 item 259).

\section{SUMMARY \\ Corporate Consistency and the Regulations of the Corporate Governance System}

Corporate governance involves not only working out the relationship between a company and its shareholders, but also a search for consistency on a daily basis. When consistency is achieved, the shareholders' satisfaction is higher and relations improve. Consistency is a prerequisite for a company's effectiveness and efficiency, and it is the board's task to make a corporation consistent. The first part of the paper introduces M. Flieger's concept of corporate consistency, where platforms of consistency are introduced and the consistency model is proposed. This is the first time that such an introduction has been made, and this may lead to further discussion and research. The author points out that managers are rarely aware of the consistency problem, and there are no tools which enable a consistent system to be worked out. This makes the concept of corporate consistency worth investigating. In the second part of the paper, R. Kaminski focuses on the development of the European Union and Polish regulations, which were introduced as a consequence of the changing conditions in company activity. This section determines the content and sequence of the main issues discussed in the article. These include: the characteristics of the concept of a corporate governance system, the presentation of changes in regulations regarding a corporate governance system in the EU and the presentation of Polish regulations on corporate governance. The primary sources used in the work were literature and the rules and standards (mandatory and optional) on corporate governance. Both authors used descriptive analysis and the comparative method.

Keywords: corporate consistency, consistency concept, platforms of consistency, consistency model, corporate governance, $\mathrm{UE}$ regulations 
234 | Adam Mickiewicz University Law Review

Ryszard Kamiński, Adam Mickiewicz University Poznań, Faculty of Law and Administration, Al. Niepodległości 53, 61-714 Poznań, Republic of Poland, e-mail: ryszard. kaminski@amu.edu.pl.

Micha£ Flieger, Adam Mickiewicz University Poznań, Faculty of Law and Administration, Al. Niepodległości 53, 61-714 Poznań, Republic of Poland, e-mail: michal. flieger@amu.edu.pl. 